\title{
Design of Disc on Disc Wear Test Equipment Using VDI 2221 Method
}

\author{
Dedi Rosa Putra Cupu, a,* and Nandha Syamza, \\ a) Laboratory Technology Construction, Mechanical Engineering Department, Universitas Riau, Indonesia \\ b) Mechanical Engineering, Universitas Riau, Indonesia
}

*Corresponding author: dedi.cupu@lecturer.unri.ac.id, nandha.syamza6019@ student.unri.ac.id

\section{Paper History}

Received: 20-August-2021

Received in revised form: 19-October-2021

Accepted: 30-November-2021

\begin{abstract}
This study aims to design the build of a wear test tool or a tribometer that intends to measure the coefficient of friction and wear rate in contact materials in form of disc-on-disc. This tribometer test tool can be used in dry contact (without any intermediate material between contacts) or wet contacts (by using intermediate material between contacts such as lubricant). The application of this disc-on-disc type of tribometer is the contact that occurs between roller elements (solid cylinders) and inner rings on cylindrical rolling bearings. In this paper is used the design method of VDI 2221. The steps are to clarify the task, determine the function of structure, look for the principle of the solution and its structure, describe the variants that can be realized and give shape to the model and detail the manufacture and used. This tool is used to test components consisting of two discs where the material can be varied. The design of the surface contact side mechanism is done in a radial direction. So, the disc can rotate (rolling contact) and this test tool can be varied load and rotation. The final result of this study is an engineering document in the form of layout drawings and assembly images as well as detailed images of each component and bills of materials.
\end{abstract}

KEY WORDS: Design, VDI 2221, Disc-on-disc, Friction.

$\begin{array}{ll}\text { NOMENCLATURE } \\ \mu & \text { Coefficient of Friction } \\ F_{n} & \text { Force } \\ Q & \text { Wear Volume } \\ S R R & \text { Slide to Ratio } \\ K & \text { Wear } \\ k & \text { Constant } \\ N & \text { Normal Force }\end{array}$

$\begin{array}{ll}\text { Fs } & \text { Friction } \\ \mu s & \text { Sliding Speed }\end{array}$

\subsection{INTRODUCTION}

Friction is the loss of energy due to the occurrence of two objects in contact [1]. Friction can also cause damage to particles of a material called wear. Wear is the loss of material on the part of the contact surface that occurs as a result of relative motion on the surface [2]. Wear occurs when two objects press against each other and rub against each other. Factors that affect wear are speed, pressure, surface roughness and material. Softer materials usually have more wear.

The level of wear of machine components that come into contact is influenced by the load received, surface roughness, mechanical properties of the material, and the lubrication carried out. One of the methods used to reduce the wear and tear that occurs is to provide lubricant on the surfaces of the components that are in contact with each other. However, wear will still occur and the wear factor cannot be eliminated and also wear can only be reduced by studying the nature of the wear.

To measure the level of friction or wear, a tribometer is needed. There are several types of tribometers depending on the type of contact that occurs, such as the pin-on-disc tribometer to observe the contact that occurs between the ball bearing element and the inner or outer ring on the ball bearing, the disc-on-disc type tribometer to describe the contact that occurs in the ball bearing. bearing element in the form of a solid cylinder with an inner or outer ring on a cylindrical roller bearing [3]. The tribometer used is a component that consists of 2 discs (disc-on-disc). The design of the disc-on-disc friction test instrument aims to measure the frictional force between two discs that have a disk-like shape with a certain thickness in the form of a diameter plate [4].

Design is an activity in the early stages of a series in the product manufacturing process. At the design stage, important decisions are made that affect other activities, so that before a product is made, a design process is carried out which will produce a technical drawing of the product to be made. The design and manufacture of products are two important activities, the design of the designer's work is of no use if the 
design is not made, and vice versa if the designer cannot realize the engineering object without first drawing the design [5].

\subsection{METHOD}

Methods are steps taken by researchers in order to gather information. The research method provides an overview of the research design which includes procedures and steps that must be taken, research time, data sources, and problem solving methods.

\subsection{VDI 2221}

The design using the VDI 2221 (Verein Deutcher Ingenieure) method is a method with a systematic approach to solving problems and optimizing the use of materials and technology [6]. The systematic VDI 2221 design method is expected to make it easier for designers to master the design system without having to master the details.

This method helps simplify the process of designing a product and facilitates the learning process for beginners and can optimize the productivity of designers to find the most optimal problem solving. There are 4 stages of work steps in the VDI 2221 method such as Clarification of Task, Coenceptual Design, Embodiment Design, and Detail Design [6]. The schematic diagram of the VDI 2221 method can be seen in Figure 1 [7].

\subsection{Tribometer disc-on-disc}

The basic principle of the disc-on-disc tribometer engine is described by a disc loaded with a normal force $\mathrm{FN}$ and rotating with velocities $\mathrm{n} 1$ and $\mathrm{n} 2$. When the speed of the disc is not equal to the frictional force vector with the same norm but in different directions then it occurs on the surface of the two discs. This force ultimately determines the frictional performance of the tribological system and therefore the desired amount to be measured [8]. Figure 2 is the basic principle of a disc-on-disc tribometer.

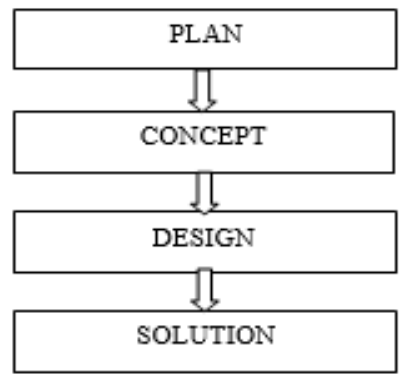

Figure 1: Schematic diagram of VDI 2221 method [7]

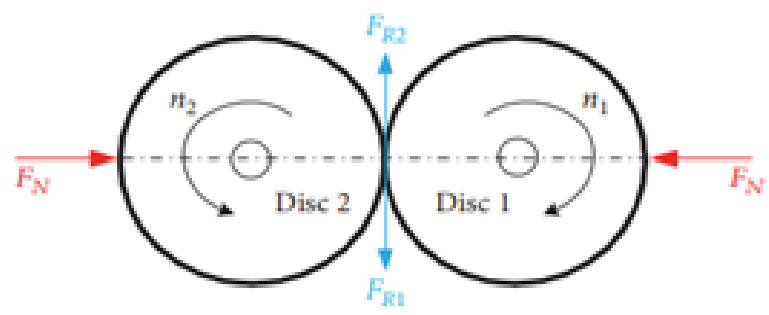

Figure 2: Disc-on-disc tribometer basic principles [9]
There are several disc-on-disc tribometer parameters which include input variable and output variable. The input variables include slide to ratio (SRR), temperature, and speed, while the output variables include wear rate and coefficient of friction [10].

\subsection{Research Method}

The research method used is the analytical method and the validation method. The flow chart in this study can be seen in Figure 3. Steps of research such as determine the function structure of the product to be made; select types of tribometer testing machines that already exist; compute the decision matrix and finally, analyze the result.

\subsection{Function Structure}

Determining the function structure of the product to be made to state how the workflow of the product is shown in Figure 4.

\subsection{Product Concept Selection}

With various types of tribometer testing machines that already exist, criteria can be taken as consideration that can be used to design disc-on-disc wear test equipment. Based on these criteria, in this research there are three design concepts illustrated in Figures 5,6,7 to be the basis for consideration.

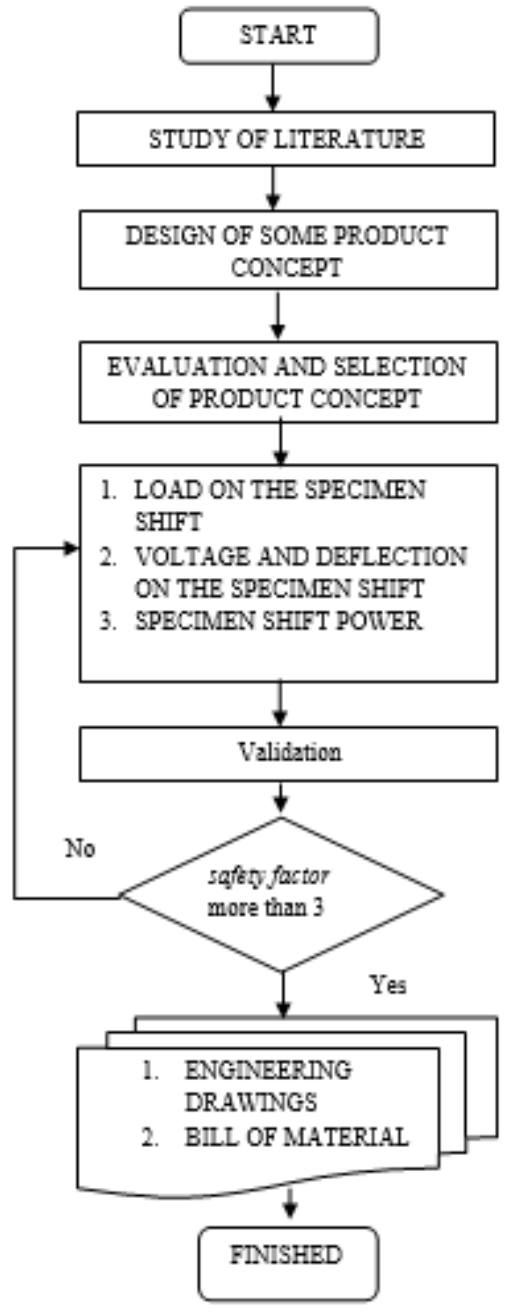

Figure 3: Research flowchart 

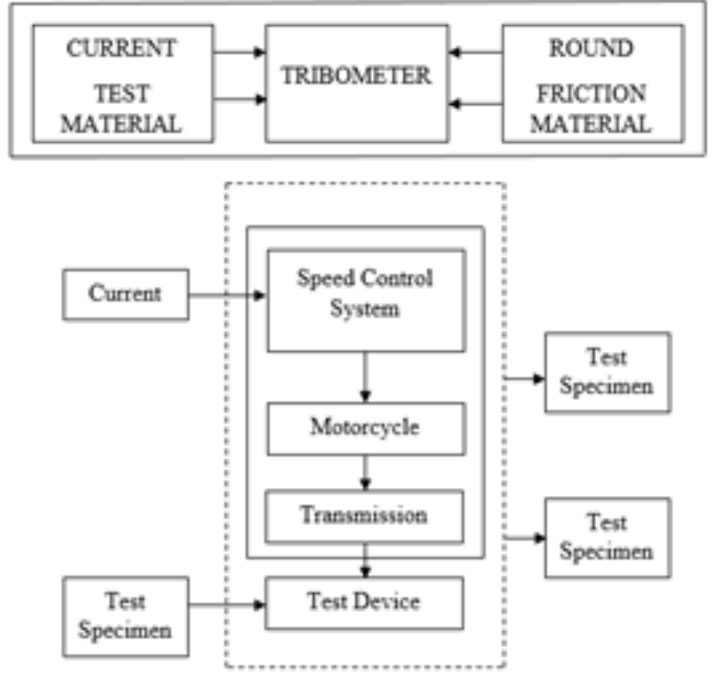

Figure 4: Functional structure of the wear test tool

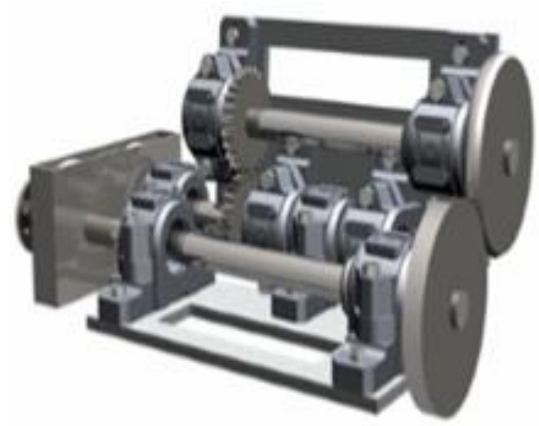

Figure 5: Concept I [11]

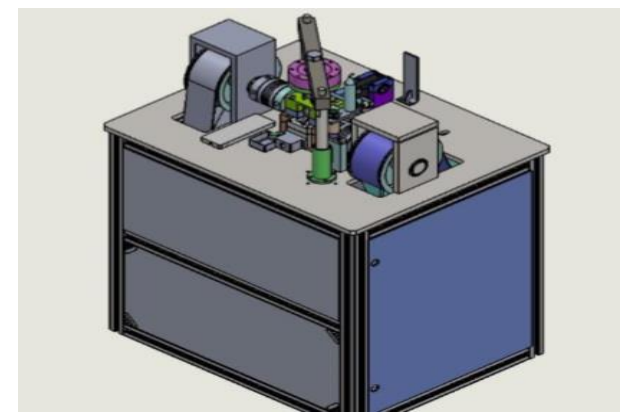

Figure 6: Concept II [12]

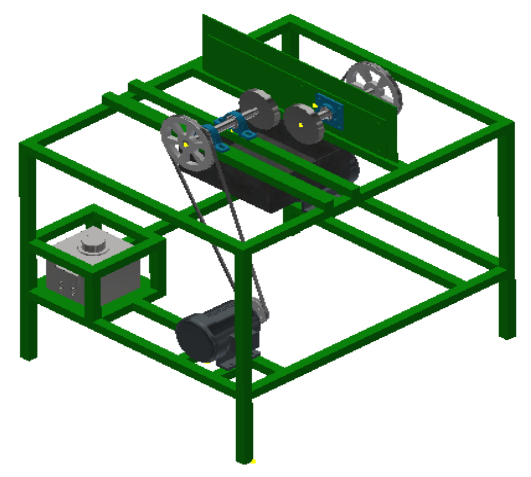

Figure 7: Concept III

\subsection{Decision Matrix Evaluation}

The decision matrix method or the Pugh method is a simple and proven method for comparing alternative product concepts $[13,14]$. The various product concept evaluation methods, the Pugh method is used as the basis for making decisions from the three existing product design concepts.

Table 1: Decision matrix

\begin{tabular}{|c|c|c|c|c|c|}
\hline \multirow[t]{2}{*}{ No } & \multirow[t]{2}{*}{ Criteria } & \multirow[t]{2}{*}{$\mathrm{wt}$} & \multicolumn{3}{|c|}{ Draft } \\
\hline & & & KI & K-II & K-III \\
\hline 1 & Shaft rotation & 10 & 10 & 10 & 10 \\
\hline 2 & $\begin{array}{l}\text { Specimen } \\
\text { round }\end{array}$ & 10 & 10 & 10 & 10 \\
\hline 3 & $\begin{array}{l}\text { Different } \\
\text { rounds }\end{array}$ & 10 & 10 & 10 & 10 \\
\hline 4 & Flexibility & 8 & 4 & 2 & 8 \\
\hline 5 & Load setting & 10 & 8 & 4 & 7 \\
\hline 6 & Torque setting & 10 & 5 & 5 & 9 \\
\hline 7 & Anticipate shaft & 9 & 5 & 9 & 8 \\
\hline 8 & Anti-slip & 9 & 8 & 8 & 8 \\
\hline 9 & Shaft speed & 6 & 5 & 2 & 5 \\
\hline 10 & Disc test & 10 & 10 & 10 & 10 \\
\hline 11 & $\begin{array}{l}\text { Lubrication } \\
\text { system }\end{array}$ & 6 & 2 & 2 & 2 \\
\hline 12 & Operation & 7 & 5 & 5 & 5 \\
\hline 13 & Low cost & 6 & 3 & 3 & 3 \\
\hline 14 & Ergonomic & 8 & 2 & 2 & 3 \\
\hline 15 & Practical tools & 8 & 2 & 2 & 4 \\
\hline 16 & $\begin{array}{l}\text { There are } \\
\text { sensors }\end{array}$ & 10 & 10 & 10 & 10 \\
\hline 17 & Easy to make & 9 & 3 & 3 & 7 \\
\hline \multirow[t]{2}{*}{18} & $\begin{array}{l}\text { Easy to } \\
\text { maintenance }\end{array}$ & 7 & 7 & 7 & 7 \\
\hline & Amount & 153 & 109 & 104 & 126 \\
\hline
\end{tabular}

\subsection{Analytical Method Analysis}

In this study, the calculation analysis was carried out on the frame and axle. The following is the calculation of the frame and axle in this design:

\section{Upper Frame}

In Figure 8 this main frame statistical analysis, the frame is modeled into one rod which is carried out to simplify the calculation process. The free body diagram of the frame can be seen in Figure 9.

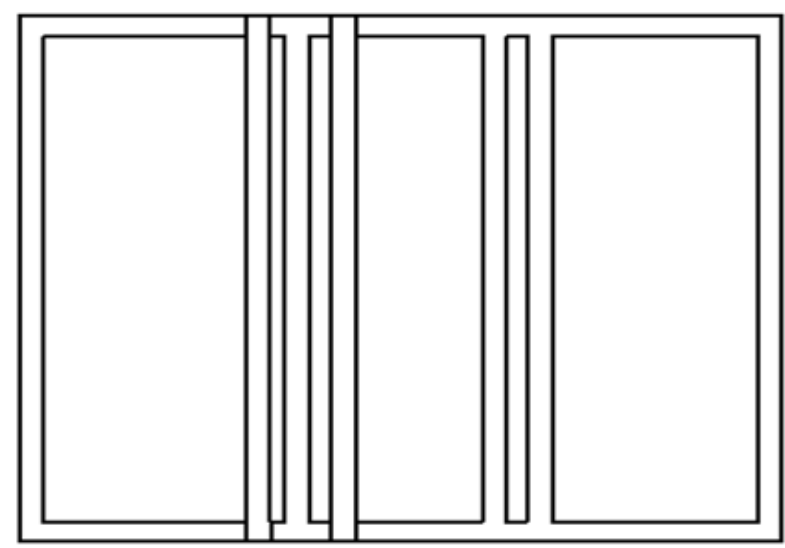

Figure 8: Upper frame 


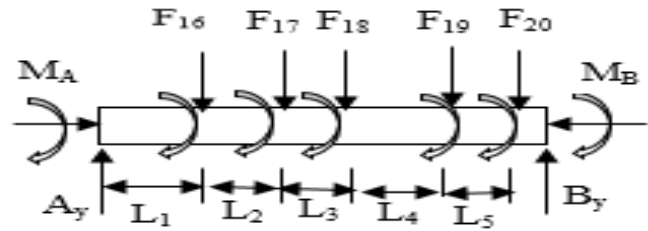

Figure 9. Upper frame DBB

From the calculations that have been done manually on the framework, the result is shown in Table 2.

Table 2: Value of shear force and moment

\begin{tabular}{|c|c|c|c|c|}
\hline No & Piece & $\begin{array}{c}\text { Shear } \\
\text { Force } \\
(\mathrm{N})\end{array}$ & Equation of Momen & $\begin{array}{c}\text { Moment } \\
(\mathrm{Nmm})\end{array}$ \\
\hline 1 & $(0 \leq \mathrm{x}<300)$ & 54.92 & $\mathrm{M}=54.92 \mathrm{X}$ & 0 \\
\hline 2 & $(300 \leq \mathrm{x}<353)$ & 25 & $\mathrm{M}=25 \mathrm{X}+9007.1$ & 16507.1 \\
\hline 3 & $(353 \leq \mathrm{x}<406)$ & 10.33 & $\mathrm{M}=10.33 \mathrm{X}+14200.8$ & 17847.3 \\
\hline 4 & $(406 \leq \mathrm{x}<595)$ & -19.59 & $\mathrm{M}=26379.4-19.59 \mathrm{X}$ & 18425.9 \\
\hline 5 & $(595 \leq \mathrm{x}<682)$ & -48.52 & $\mathrm{M}=43622.8-48.52 \mathrm{X}$ & 14573.4 \\
\hline 6 & $(682 \leq \mathrm{x}<969)$ & -53.42 & $\mathrm{M}=46969.7-53.42 \mathrm{X}$ & 10537.3 \\
\hline
\end{tabular}

\section{Lower Frame}

The analysis of the calculation of the lower frame is shown in Figure 10. The free body diagram on the frame can be seen in Figure 11.

From the calculations that have been done manually on the framework, the results are shown in Table 3.

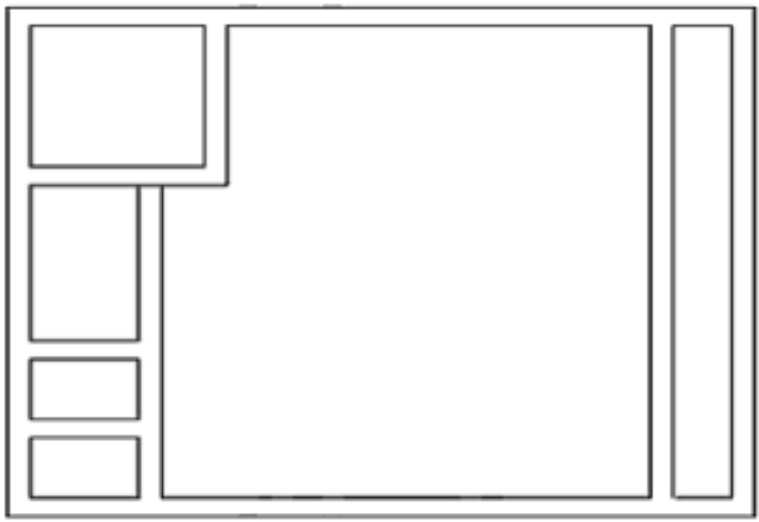

Figure 10: Lower frame

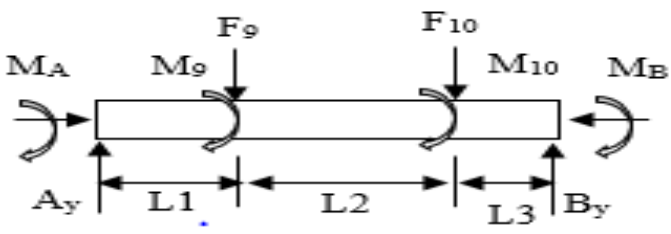

Figure 11. Lower skeletal DBB
Table 3: Values of shear force and moment

\begin{tabular}{|c|c|c|c|c|}
\hline No & Piece & $\begin{array}{c}\text { Shear } \\
\text { Force } \\
(\mathrm{N})\end{array}$ & Equation of Moment & $\begin{array}{c}\text { Moment } \\
(\mathrm{Nmm})\end{array}$ \\
\hline 1 & $(0 \leq \mathrm{x}<180)$ & 285.27 & $\mathrm{M}=285.27 \mathrm{X}$ & 0 \\
\hline 2 & $(180 \leq \mathrm{x}<830)$ & 79.17 & $\mathrm{M}=79.17 \mathrm{X}+37205.2$ & 51455.8 \\
\hline 3 & $(830 \leq \mathrm{x}<950)$ & -48.36 & $\mathrm{M}=143121.3-48.36 \mathrm{X}$ & 102982.5 \\
\hline
\end{tabular}

3. Axis

To be able to determine the strength of the design results, the value of these loads must be known in the following way: a. Load analysis due to V-belt voltage:

$$
\begin{aligned}
M_{1}= & 9555 \times \frac{P}{n} \\
= & 9555 \times \frac{172}{1440} \\
M_{1}= & 1141.29 \mathrm{Nm}
\end{aligned}
$$

Diameter of pulley D1 $=101.6 \mathrm{~mm}$ :

$$
\begin{aligned}
T_{e} & =\frac{2 . M_{1}}{d_{1}} \\
& =\frac{2 \times 1141.29 \mathrm{Nm}}{101.6 \mathrm{~m}} \\
T_{e} & =22.46 \mathrm{~N} \\
T_{1} & =T_{e}+T_{2} \\
& =22.46+6.73 \\
& =29.20 \mathrm{~N}
\end{aligned}
$$

Because the diameter of the pulley is different $(\mathrm{D} 1 \neq \mathrm{D} 2)$, it can be calculated as follows:

$$
\begin{aligned}
F & =\sqrt{T_{1}^{2}+T_{2}^{2}-2 T_{1} T_{2} 3(2 \cos \alpha)} \\
& =\sqrt{29.20^{2}+6.73^{2}-2 \times 29.20 \times 6.73(2 \cos 6.143)} \\
& =\sqrt{897.93-781.55)} \\
& =\sqrt{116.38} \\
& =10.78 \mathrm{~N}
\end{aligned}
$$

Compressive load analysis:

$$
\begin{aligned}
F_{n} & =\frac{2 . M_{2}}{\mu_{s} \cdot d_{s}} \\
\mu_{s} & =\frac{2 . M_{2}}{F_{n} \cdot d_{s}} \\
\mu_{s} & =\frac{2 \times 2.13}{100 \times 10} \\
\mu_{s} & =0.00426
\end{aligned}
$$

The coefficient of static friction for maximum load of $130 \mathrm{~mm}$ specimen diameter is as follows:

$$
\begin{aligned}
F_{n} & =\frac{2 \cdot M_{2}}{\mu_{s} \cdot d_{s}} \\
\mu_{s} & =\frac{2 \cdot M_{2}}{F_{n} \cdot d_{s}} \\
\mu_{s} & =\frac{2 \times 2.13}{100 \times 130} \\
\mu_{s} & =0.000327
\end{aligned}
$$


b. Strength Due to Maximum Shear Load

$$
\begin{aligned}
\tau_{0} & =\frac{\sigma_{y}}{\sqrt{3}} \\
\tau_{0} & =\frac{207}{\sqrt{3}} \\
\tau_{0} & =119.5 \frac{\mathrm{N}}{\mathrm{mm}^{2}}
\end{aligned}
$$

c. Normal Load Strength or MPFP $\left(\sigma_{\max }\right)$

$$
\begin{aligned}
\sigma_{\max } & \leq \frac{\sigma_{u}}{F_{k}} \\
4.9 & \leq \frac{330}{61.36} \mathrm{MPa} \\
4.9 & \leq 5.37 \mathrm{MPa}
\end{aligned}
$$

So the result of this calculation is $4.9 \leq 5.37 \mathrm{MPa}$ which indicates that the shaft is able to withstand the load.

\subsection{RESULTS}

The design of several product concepts that have been made, then the assessment of the three product concepts is assessed using the Pugh decision matrix which has the largest criteria and value obtained in concept 3 .

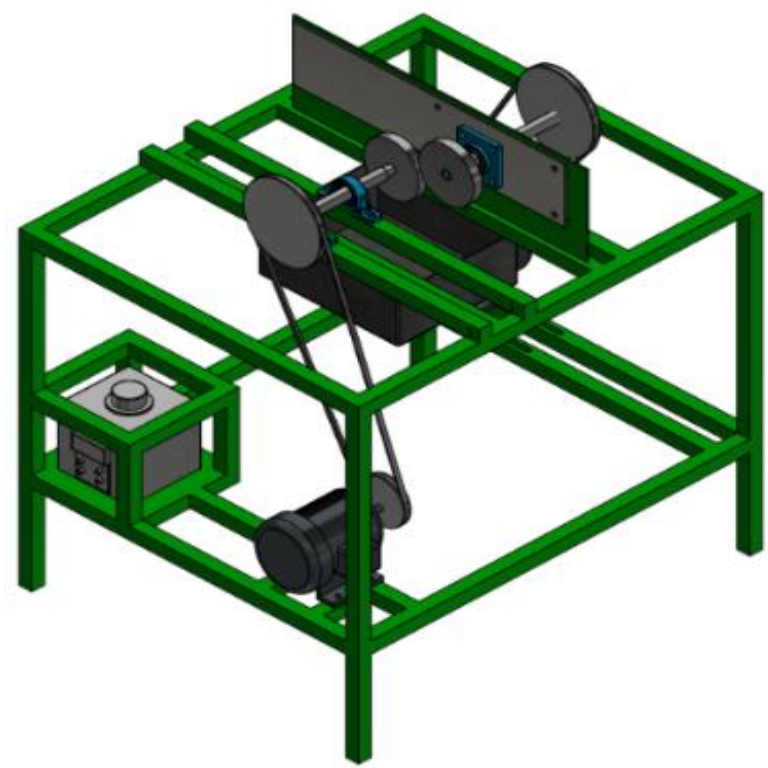

Figure 12: Selected concept

\subsection{Autodesk Inventor Analysis Results}

1. Mainframe Static Validation Results

Based on the simulation using the software inventor, it can be seen the maximum stress, von misses, and safety factor contained in the main frame. In Figure 13 (a), (b) and (c) that can be seen the results of the simulation software inventor.

Based on Figure 13 (a), the results of the validation that have been carried out are known that the maximum stress that occurs in the main frame is $39.22 \mathrm{MPa}$ and the minimum stress is $-12.85 \mathrm{MPa}$. Figure 13 (b), Von Misses that occurs in the main frame is $38.31 \mathrm{MPa}$ which is located on the adjustable seat rod.

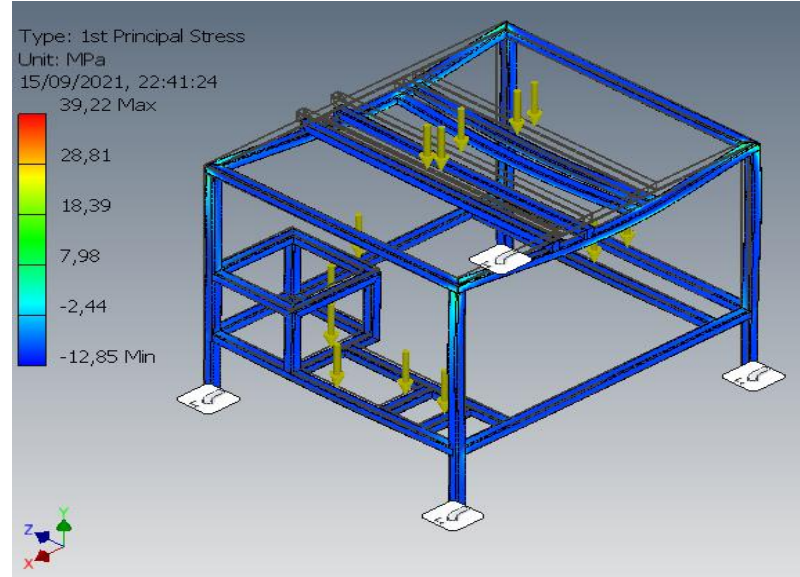

(a)

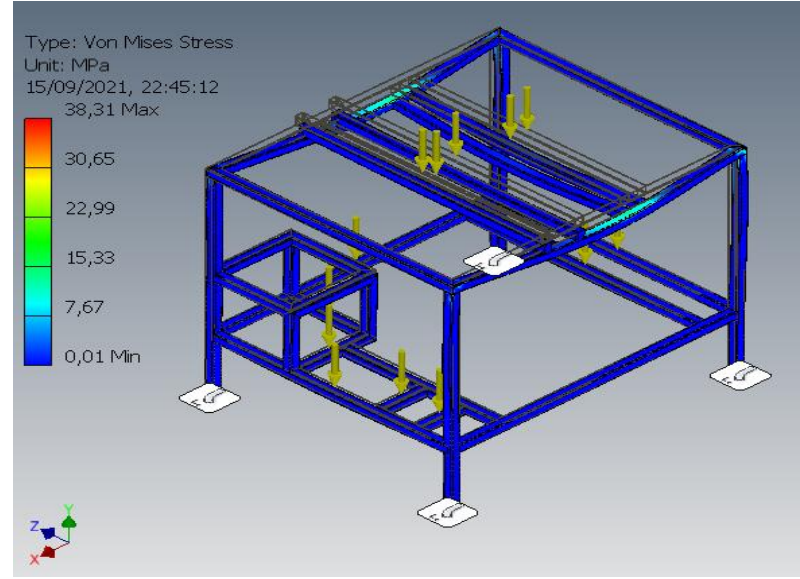

(b)

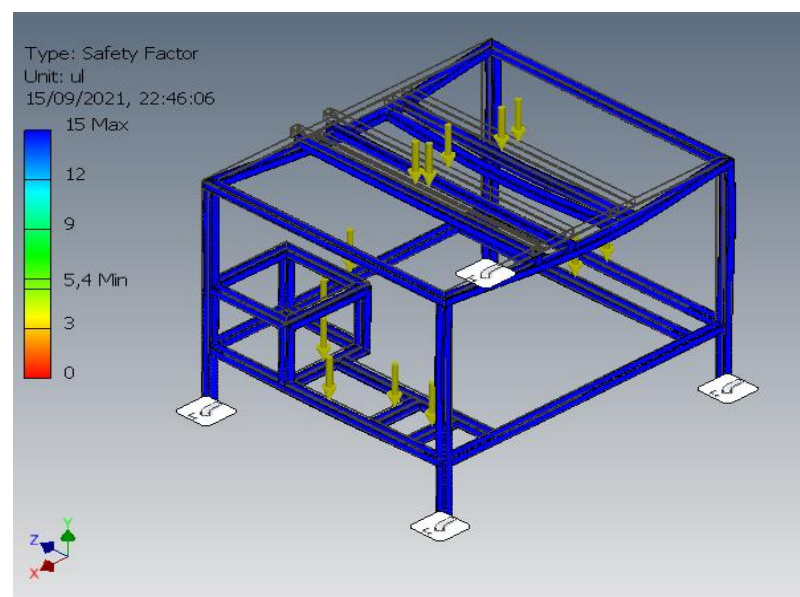

(c)

Figure 13: Frame validation results, (a) maximum stress, (b) Von Misses, and (c) Safety factor

In Figure 13 (c), the results of the validation that have been carried out in a simulation using the software inventor, it can be seen that the parts of the frame with the smallest safety factor value are on the adjustable rod. The calculation obtained in the simulation using software inventor the safety factor value obtained is 5.4. 
2. Shaft Validation Results

From the simulation using the software inventor, it can be seen the maximum stress, displacement, and safety factor contained in the shaft. The results can be seen in Figure 13 (a), (b) and (c).

Based on Figure 14 (a) it is known that the deflection that occurs on the shaft is 0.004661 which is located at the end of the shaft connected to the pulley. Figure 14 (b) the maximum stress that occurs is $2.6 \mathrm{MPa}$ which is located on the shaft connected to the bearing. In the simulation calculation of the software inventor, the maximum stress value obtained is $2.6 \mathrm{MPa}$.

Figure 14 (c) from the calculations that have been carried out in a simulation using the software inventor, it can be seen that the part of the shaft with the smallest safety factor value is in the bearing. In the simulation calculation using the software inventor, the safety factor value obtained is $5.54 \mathrm{MPa}$.

\subsection{Analysis and Discussion}

1. Frame

Based on the results of the calculations and analyzes that have been carried out on the main frame, the maximum stress that occurs in the main frame is $63.00 \mathrm{MPa}$ while the shear stress is $7.69 \mathrm{MPa}$. Calculation of von misses obtained results of $60.5 \mathrm{MPa}$ and safety factor obtained results of $4.46 \mathrm{MPa}$. The following are the results of the calculation of the framework in Table 4.

The results of the simulation using Inventor software can determine the maximum stress, von misses and safety factor contained in the shaft. The Result of framework validation used the software inventor simulation is shown in Table 5.

Table 4: Results of frame calculation

\begin{tabular}{ccccc}
\hline Analysis & $\begin{array}{c}\text { Main } \\
\text { max }\end{array}$ & Shift & $\begin{array}{c}\text { Von } \\
\text { Misses }\end{array}$ & $\begin{array}{c}\text { Safety } \\
\text { Factor }\end{array}$ \\
\hline $\begin{array}{c}\text { Analysis } \\
\text { Results }\end{array}$ & 28.81 & 0.76 & 50.7 & 5.32 \\
\hline
\end{tabular}

Table 5: Results of framework validation

\begin{tabular}{rcccc}
\hline \multicolumn{5}{c}{ Analysis Results } \\
\hline No & Score & $\begin{array}{l}\text { Maximum } \\
\text { Voltage }\end{array}$ & $\begin{array}{l}\text { Von } \\
\text { Misses }\end{array}$ & $\begin{array}{l}\text { Safety } \\
\text { Factor }\end{array}$ \\
\hline 1 & Max & 39.22 & 38.31 & 15 \\
2 & Min & -12.85 & 0 & 5.4 \\
\hline
\end{tabular}

2. Axis

Based on the results of calculations and analysis on the shaft, the normal stress is $4.9 \mathrm{MPa}$ while the shear stress is $2.5 \mathrm{MPa}$. Displacement of $0.00114 \mu \mathrm{m}$ and a safety factor of $5.37 \mathrm{MPa}$, which can be seen in Table 6 .

The results of the simulation with the software inventor can determine the maximum stress, displacement, and safety factor contained in the shaft. The following are the results of the software inventor simulation in Table 7 .

\begin{tabular}{ccccc}
\multicolumn{5}{c}{ Table 6: Shaft calculation results } \\
\hline \multirow{2}{*}{ Analysis } & \multicolumn{2}{c}{ Stress (Mpa) } & Von & Safety \\
& Normal & Shift & Misses & Factor \\
\hline Results & 4.9 & 2.5 & 0.114 & 5.37
\end{tabular}

Table 7: Shaft validation results

\begin{tabular}{ccccc}
\hline \multicolumn{5}{c}{ Analysis Results } \\
\hline No & Score & Displacement & $\begin{array}{l}\text { Von } \\
\text { Misses }\end{array}$ & $\begin{array}{l}\text { Safety } \\
\text { Factor }\end{array}$ \\
\hline 1 & Mak & 0.004661 & 2.6 & 15 \\
2 & Min & 0 & 0 & 5.54 \\
\hline
\end{tabular}

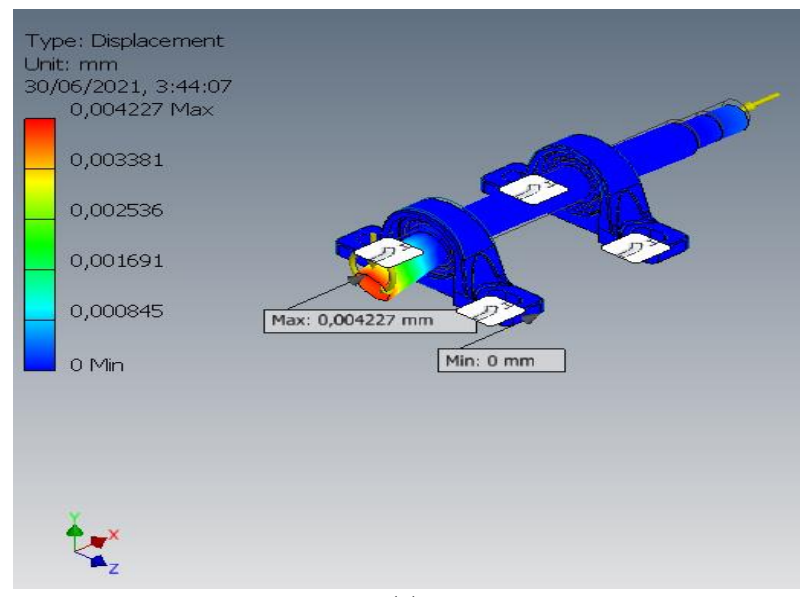

(a)

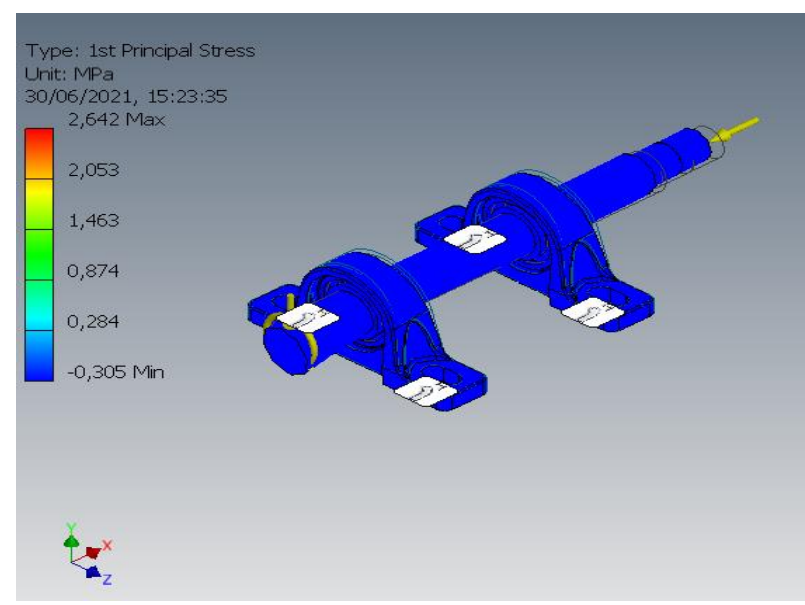

(b)

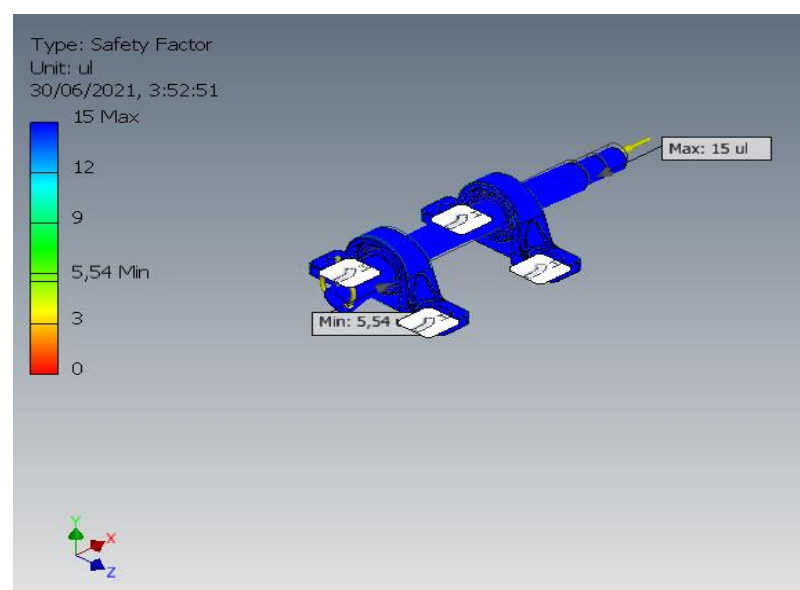

(c)

Figure 14: Shaft validation results, (a) displacement, (b) maximum stress, and (c) safety factor 


\subsection{CONCLUSION}

The design of wear test equipment based on a disc-on-disc contact system using the VDI 2221 method has been validated and analyzed in this paper. So, this test tool can be used to test the wear and friction coefficient on disc specimens with a minimum diameter of $10 \mathrm{~mm}$ and a maximum of $130 \mathrm{~mm}$ with a rotation that is can be varied from 0 to $1440 \mathrm{rpm}$. The results of technical drawings and bill of materials on this disc-on-disc wear tester are in accordance with ISO Standards. The main components of this disc-on-disc wear tester consist of the frame, shaft, pulley, bearing, disc and electric motor. From the results of the analysis that has been carried out on the frame by calculation, the maximum stress value is $63.00 \mathrm{MPa}$, shear stress of $7.69 \mathrm{MPa}$, von misses of $60.5 \mathrm{MPa}$ and the safety factor of $4.46 \mathrm{MPa}$. For the calculated shaft, the normal stress value is $4.9 \mathrm{MPa}$, shear stress of $2.5 \mathrm{MPa}$, displacement of $0.00114 \mu \mathrm{m}$ and the safety factor of $5.37 \mathrm{MPa}$.

\section{REFERENCES}

[1] Samuel, A. \& Weir, J. (1999). Introduction to Engineering Design. Elsevier Science \& Technology Books, ISBN: 0750642823, Melbourne.

[2] Hegadekate, V., Kurzenha user, S., Huber, N. \& Kraft, O. (2008). A predictive modeling scheme for wear in tribometers, Tribology International, 41, 1020-1031.
[3] Sularso (2004). Machine Element. PT. Pradya Paramita, Jakarta.

[4] Budynas, R.G. \& Nissbet, J.K. (2008). Shigley's Mechanical Engineering Design. $8^{\text {th }}$ Edition in SI Unit. New York: McGraw-Hil.

[5] Stachowiak, G. \& Batchelor, A. (2005). Engineering Tribology. Oxford: Elsevier.

[6] Bhushan, B. (2013). Introduction of Tribology. New York: Wiley.

[7] Zum - Gahr, K.H. (1987). Microstructure and Wear of Materials. Elseiver, Amsterdam, The Netherlands.

[8] Stachowiak, G.W. (2005). Wear - Materials, Mechanisms and Practice.

[9] Shigley, J.E., Mitchell, L.D. in translator by Harahap, G. (1986). Mechanical Engineering Design. Fourth Edition Volume 1. Jakarta : Erlangga.

[10] Sularso; Suga, Kiyokatsu (2002). Basic Planning and Selection of Machine Elements. Pradnya Paramita: Jkr.

[11] Mott, R.L. (2009). Machine Elements in Mechanical Design (Integrated Machine Element Design) 1. Yogyakarta: Andi Publisher.

[12] Popov, E.P. in translator: Astamar, Z. (1996). Mechanical Mechanics. Second Edition. Jakarta: Erlangga.

[13] Londa, P. (2013). Design of Running Test Equipment for Disc Paired Contact System and Gear. Pairs, Semarang.

[14] Guler, K. \& Petrisor, D.M. (2021). A pugh matrix based product development model for increased small design team efficiency, Cogent Engineering, 8(1), 1-17. 